\title{
Associações leigas católicas: novos espaços, práticas religiosas e perspectivas no séc.XX
}

\section{Catholic lay associations: new settings, religious practices and perspectives in the 20th century}

Edilece Souza Couto*

Resumo: As primeiras décadas do século XX, na Bahia, foram marcadas pelas tentativas de modernização urbana e civilização dos costumes, especialmente na capital. Autoridades políticas e religiosas uniram-se em torno de um projeto de modernização gestado e executado em dois diferentes mandatos do governador José Joaquim Seabra (1912-1916 e 1920-1924). Porém, o recorte temporal foi estendido até 1938 a fim de abarcar algumas mudanças, como a demolição da Igreja da Sé, que, apesar de previstas, só ocorreram na gestão do interventor federal Juracy Magalhães (1931-1937). Nesse contexto, muitas associações leigas foram forçadas a realizar transferências para outras igrejas. Esse artigo trata dos deslocamentos de espaço, as consequentes mudanças nas práticas religiosas dos fiéis e suas perspectivas de continuidade no século XX..

Palavras-chave: Associações leigas; catolicismo; modernização; século XX; Salvador - BA

\footnotetext{
* Professora do Departamento de História da Universidade Federal da Bahia (UFBA), Brasil E-mail: edilece@ufba.br
} 


\begin{abstract}
The first decades of the 20th century in Bahia were marked by attempts of urban modernization and custom civilization, particularly in the capital. Political and religious authorities united towards a modernization project conceived and executed in two different terms of Governor José Joaquim Seabra (1912-1916 and 1920-1924). However, the timeframe was extended until 1937 in order to comprehend some changes, such as the demolition of Sé Church; although these changes had been planned, they only occurred along the term of federal auditor Juracy Magalhães (1931-1937). In that context, several lay associations were forced to move to other churches. This paper approaches the displacements, the consequent changes in the religious practices of believers and the perspectives of continuity in the 20th century.
\end{abstract}

Keywords: Lay associations; Catholicism; modernization; 20th century; Salvador- BA

Da colônia ao império no Brasil, os principais agentes do catolicismo foram os leigos. O clero era responsável pela realização da liturgia e dos sacramentos, mas a insuficiência numérica e a má formação dos padres fez com que as devoções, procissões e festas aos santos estivessem a cargo dos fiéis. As práticas religiosas poderiam acontecer nas residências, em oratórios e nichos de forma individualizada ou familiar. Porém, os devotos transformaram as obrigações pessoais em vivências coletivas do sagrado e criaram laços de solidariedade e sociabilidade que venceram as agruras do tempo, os deslocamentos forçados e as intervenções clericais, chegaram ao século XX e alguns grupos permanecem na atualidade.

\title{
Associações leigas católicas
}

São denominadas associações leigas católicas as organizações de fiéis formadas a partir de critérios de cor da pele, socioeconômicos ou, simplesmente, pela vinculação ao catolicismo. Os devotos não eram ordenados, mantinham famílias, escolhiam um santo patrono e desenvolviam, com certa independência da Igreja Católica, a sua devoção, seus ritos e suas festas. Na Europa, esses grupos tiveram origem no século XIII e possuem muitos termos: fraternidade, sociedade, congregação, pia união, irmandade, confraria, ordem terceira, etc. No Brasil colonial eram denominados irmandade, confraria e ordem terceira. ${ }^{1}$ O Código de Direito Canônico, de 1918, traz apenas as seguintes terminologias: ordem terceira, confraria e pia união. Farei referência a irmandade, confraria e ordem terceira, pois, as associações leigas da Bahia nos séculos XIX e XX assim se autodenominavam e a documentação eclesiástica do período também utiliza esses termos.

As associações leigas possuíam objetivos comuns, como manter o 
culto ao padroeiro e desenvolver a ajuda mútua entre os associados. Eram geridas por uma mesa administrativa e funcionavam quase sem interferência clerical. O regimento interno, chamado de compromisso ou estatutos a partir da segunda década do século XX, estabelecia as regras de admissão dos sócios, administração e normas para a oficialização do culto. Deveria estar de acordo com a legislação eclesiástica em vigor, primeiramente as Constituições Primeiras do Arcebispado da Bahia (1707) e Código de Direito Canônico a partir de 1918, e ser aprovado pela autoridade eclesiástica (bispo ou arcebispo). Se fosse uma filial de alguma associação portuguesa, o compromisso deveria ser enviado para aprovação pela matriz. Eram responsáveis pela contratação de um padre para a realização dos ofícios. Assim, ele apenas celebrava as missas e ministrava os sacramentos.

Todas as características acima estão relacionadas às irmandades, porém, apesar dessa estrutura comum, as associações eram distintas em outros aspectos. A exclusiva vinculação religiosa das irmandades as diferem das confrarias, uma vez que essas são organizadas a partir de um vínculo profissional. As confrarias tiveram origem nas corporações de ofício da baixa Idade Média. Dessa forma, o critério de admissão dos membros era a pertença a um mesmo grupo profissional. Porém, enquanto os ofícios estavam relacionados ao trabalho, as confrarias tinham como principal objetivo a promoção do culto católico. Assim, elegiam um padroeiro de acordo com as funções e características de um santo ligado à profissão. Ex. Santa Cecília para a confraria dos músicos, São José para os carpinteiros, etc. A confraria era "a face religiosa" da corporação. Era a forma do confrade obter auxílio em momentos de doença e invalidez e garantir o sepultamento com ritos e em cemitério cristão ${ }^{2}$. No Brasil, muitas vezes os termos irmandade e confraria aparecem como sinônimos, pois grupos sem vínculos profissionais se autodenominaram confraria. Na Bahia, esse é o caso da Irmandade do Senhor Bom Jesus da Cruz, formada por homens pardos em 1719. O compromisso não revela a data, mas afirma que alguns anos depois adotou a denominação Fortaleza do Senhor Bom Jesus da Cruz, e em 1751 passou a se chamar Confraria do Senhor Bom Jesus da Cruz 3 .

Por sua vez, as ordens terceiras foram criadas pelo papa Inocêncio III, no século XIII, para evitar que os devotos se distanciassem da ortodoxia católica e participassem ou formassem grupos de pregação não autorizados pela Igreja, considerados heréticos. Dessa maneira foram organizadas as associações fraternais que buscam conciliar as atividades religiosas com as responsabilidades familiares. ${ }^{4}$ Elas são vinculadas às ordens religiosas regulares, sem a prática conventual. Assim, o clero passou a ter maior controle sobre a administração e o culto praticado pelos irmãos leigos.

No Brasil colonial os leigos foram incentivados pelo clero a criar associações católicas. Entretanto, os fiéis reunidos em irmandades, confrarias e ordens terceiras ampliaram as funções para além do culto. Especialmente 
os africanos e crioulos escravos e libertos aproveitaram as brechas na fiscalização eclesiástica e os encontros frequentes para desenvolver laços de identidade étnica, solidariedade, por meio da ajuda mútua em momentos de doença, morte ou mesmo na compra de alforrias. Aos poucos, os associados foram complementando o catolicismo com as práticas religiosas africanas, o que era visto pelas autoridades eclesiásticas como excessos e desvios que deveriam ser evitados e combatidos com vigilância, cumprimento das regras e respeito à legislação católica. Mas vale ressaltar que as associações de homens brancos também não estavam isentas dessas críticas e regras de conduta e administrativas.

Após o fim da escravidão, a identidade étnica deixou de ser o critério principal para a formação de uma associação leiga. Ou seja, houve mudança no significado da reunião dos leigos. Passou a vigorar nos compromissos reformulados o critério de vinculação religiosa ao catolicismo. No mapeamento das associações leigas no século XX que realizamos, das trinta e três irmandades, confrarias e ordens terceiras identificadas até o momento, tivemos acesso a oito compromissos reformulados. Esse número pode parecer pequeno, porém demonstra uma tendência de eleger como critério de pertencimento não mais a nação a qual pertencia os africanos e a cor da pele. Essa mudança também era reivindicada pelo arcebispado e confirmada na legislação a partir de 1918, com a publicação do Código de Direito Canônico. Todos os oito compromissos reformulados afirmam, no artigo $1^{\circ}$, que a associação é uma reunião de fiéis católicos apostólicos romanos. Nenhuma traz a informação da identidade étnica que motivou a criação no século XVIII. O capítulo II, artigo $1^{\mathrm{o}}$ do Compromisso da Confraria do Senhor Bom Jesus da Cruz (originalmente formada por homens pardos), reformulado em 1913 e reimpresso em 1914, por exemplo, determina que essa associação [...] é a reunião de todos os fiéis católicos apostólicos romanos que, por sua devoção, a ela queiram pertencer"s.

Houve uma maior valorização de outros significados já existentes, como a solidariedade, a beneficência e a sociabilidade. Em 1891, a Irmandade de Santa Cecília, por meio de ofício encaminhado ao vigário capitular, o escrivão informou que na reformulação do compromisso a mesa administrativa resolveu "ampliar a parte beneficente" a fim de "mitigar algum sofrimento dos irmãos necessitados". Já a Confraria do Senhor Bom Jesus da Cruz determina em seu art. 3 que "Só podem ser irmãos os maiores de 21 anos, salvo os casados, clérigos, os que tiverem diploma de qualquer faculdade científica ou literária, e os oficiais militares, nunca menores de 18 anos, e os filhos dos irmãos, ainda que de pequena idade e nas circunstâncias do Art. 1, e todos de boa conduta moral e religiosa" ". Até mesmo os clérigos poderiam ser admitidos na associação.

Essas transformações nas associações leigas refletem as mudanças ocorridas na Igreja Católica, na política e na sociedade brasileira a partir do final do oitocentos. O clero católico seguia as orientações da Sé romana que 
exigia reformas na formação sacerdotal e na vivência religiosa dos leigos. Dessa forma, houve maior rigor no cumprimento das normas para o culto, o que tirava a independência dos leigos na promoção das devoções. A principal exigência era que toda atividade leiga fosse dirigida e supervisionada pelo clero. Por sua vez, as autoridades civis tentavam laicizar o Estado, modernizar as cidades e civilizar a sociedade a partir dos padrões europeus. Nesse contexto, muitas associações leigas perderam poder e prestígio, tiveram suas igrejas desapropriadas, foram obrigadas aos deslocamentos e ao uso de táticas ${ }^{8}$, aproveitamento das falhas do poder instituído para burlar regras e, dessa forma, evitar o desaparecimento e manter suas devoções.

\section{Modernização, demolições de igrejas e deslocamentos}

No final do século XIX a Europa vivia a denominada belle époque. Eram recorrentes as referências à lealdade à pátria, fausto, luxo e confiança nas verdades científicas. A França era modelo de civilidade para o mundo. Segundo Walter Benjamin 9 , Paris era a Cidade Luz em função das galerias, salas de exposições e estações de trem, construídas em ferro e vidro, iluminadas a eletricidade. O barão de Haussmann, que se autodenominava o "artista demolidor" transformava a arquitetura parisiense. Demoliam-se antigas casas para abrir espaços às largas avenidas. E não parava por ai. A eletricidade permitia a iluminação de palácios e pavilhões das exposições universais, e a projeção dos filmes por meio do cinematógrafo. A velocidade também estava em alta, com metrô, automóveis e bondes elétricos, navios a vapor e máquinas voadoras, como os dirigíveis. Havia avanços também nas comunicações por intermédio do rádio, telégrafo e telefone. $\mathrm{O}$ homem parecia finalmente controlar o tempo e o espaço.

No Brasil, os políticos não mediram esforços para modernizar e civilizar o novo Estado republicano. São Paulo, Rio de Janeiro e Salvador deveriam seguir o exemplo de Paris.

Em São Paulo, as reformas urbanas começaram por volta de 1870, muito em função dos avanços e da riqueza advinda da lavoura cafeeira e da cidade ser um entreposto comercial e financeiro, porta de entrada do capital internacional no Brasil. O governador da Província, João Theodoro Xavier de Mattos, deu início ás intervenções urbanas, com a abertura de ruas e avenidas, criação de jardins públicos, do Viaduto do Chá, da Avenida Paulista (inaugurada em 1881) e bairros sofisticados como Campos Elísios e Higienópolis. Inovações na arquitetura podiam ser observadas em novos edifícios públicos para abrigar as secretarias de estado, a Escola Normal, o Instituto Histórico e Geográfico, a Escola Politécnica, a Sociedade de Medicina e Cirurgia, o Instituto Butantã, a Escola Livre de Farmácia e o Museu Paulista. Houve também valorização do uso da energia elétrica. Assim, em 1901 São Paulo teve sua Estação da Luz, 
unindo via férrea e eletricidade. ${ }^{10}$

O Rio de Janeiro, a capital do Brasil, deveria se transformar no maior cartão-postal do país. Entre 1902 e 1906, o presidente Rodrigues Alves formou uma equipe de engenheiros, médicos e higienistas a fim de realizar as intervenções. O projeto tinha três eixos: o porto, sob a responsabilidade do engenheiro Mauro Müller; o saneamento, para o controle das epidemias infecciosas, foi entregue ao médico sanitarista Oswaldo Cruz; e a reforma arquitetônica seria realizada pelo engenheiro Pereira Passos. O principal símbolo de modernidade era a Avenida Central, atual Av. Rio Branco. Os prédios, construídos com mármore e cristal, possuíam fachadas art nouveau e abrigavam lojas de produtos importados. A iluminação elétrica era feita com modernos lampiões. Eram excluídos desse espaço os pobres e negros, com seus bailados, entrudos, suas festas religiosas e procissões que lembrassem a escravidão e o período colonial. ${ }^{11}$

$\mathrm{Na}$ Bahia, políticos, médicos, sanitaristas, higienistas, educadores e articulistas dos jornais, acreditavam que Salvador, a primeira capital do Brasil, não podia ficar de fora da modernização. Defendiam a reordenação do espaço urbano para tirar a cidade do atraso colonial. Era preciso resolver os problemas de saneamento básico, abastecimento de água, serviços de esgoto e coleta de lixo, que contribuíam para as precárias condições de higiene e saúde da população, que ainda sofria com diferentes surtos epidêmicos. Essas intervenções estavam presentes no projeto de reformas urbanas de José Joaquim Seabra, que governou a Bahia em dois mandatos: de 1912 a 1916 e de 1920 a 1924. Seabra era jurista e tinha experiência na administração pública. Foi deputado, ministro da justiça na gestão de Rodrigues Alves (1902-1906), ministro da aviação e obras públicas no governo de Hermes da Fonseca (19101914), e trabalhou nas reformas do Rio de Janeiro no governo de Pereira Passos. Com base nessa experiência, Seabra pretendia fazer uma grande intervenção urbana em Salvador, com ampliação de ruas, construção de novas vias, abertura de avenidas, construção e reforma dos edifícios públicos. ${ }^{12}$

As reformas começariam pelo porto e se estenderia por toda a área comercial da cidade baixa. Porém, a obra que teria maior destaque, visibilidade e inclusão de Salvador no rol das cidades modernas e civilizadas do Brasil seria uma longa avenida, que começaria na Praça da Sé, percorreria toda a cidade alta, passando pelo centro, bairros aristocráticos como Vitória e Barra até chegar ao arrabalde do Rio Vermelho, zona de veraneio. A denominada Av. Sete de Setembro seria o cartão-postal da capital, a exemplo da Av. Paulista, em São Paulo, e da Av. Central no Rio de janeiro. Para tal empreendimento seria necessária a demolição de alguns antigos edifícios: Instituto de Higiene, Imprensa Oficial, o primeiro cartel da Vila Policial do Estado, a garagem do antigo Passeio Público, a entrada do departamento do Quartel da Cavalaria, Museu-Escola, Pavilhão de Ondina, Pavilhão Kroepelin, Pavilhão dos 
Tuberculosos, a residência do diretor, o Hospício S. João de Deus, Palácio do Progresso, as igrejas da Sé (catedral), do Mosteiro de São Bento, de São Pedro Velho, as fachadas da Igreja do Rosário, da capela e do convento das Mercês. ${ }^{13}$

Houve aliança entre o governo e a Igreja Católica para a realização das reformas. O intendente e o governador tiveram o apoio de dom Jerônimo Tomé da Silva. Ele era, inclusive, o responsável por solicitar da Santa Sé as licenças para as destruições em parte ou na totalidade de igrejas centenárias. Na verdade, desde o final do século XX, os leigos reclamavam do desrespeito por parte das autoridades aos espaços sagrados. $\mathrm{Na}$ área comercial da cidade baixa, os constantes incêndios eram motivos e justificativas para os cortes nas igrejas. Um exemplo disso foi o corte em parte da Igreja do Corpo Santo em janeiro de 1902. O intendente José Eduardo Freire de Carvalho Filho, em seu relatório ${ }^{14}$ de gestão, revelou que só conseguiu fazer a abertura de uma via ligando o Largo das Princesas à rua de Santa Bárbara porque um incêndio, ocorrido em 01 de dezembro de 1899, facilitou "um grande corte em parte da Igreja do Corpo Santo" e que contou com "os intuitos progressistas e patrióticos" do arcebispo dom Jerônimo da Silva para obter a licença da Cúria Romana.

De acordo com Michel de Certeau ${ }^{15}$, o discurso urbanístico é definido por três operações: 1. Uma produção racional que deve recalcar as poluições físicas, mentais ou políticas que a comprometeriam; 2 . Substituir as resistências teimosas das tradições, ou seja, substituir as táticas dos usuários; 3. Na cidade combinam-se gestão e eliminação. Rejeitam-se os detritos (anormalidade, desvio, doença, morte, etc.). A gestão funcionalista privilegia o progresso. A cidade-conceito, lugar de transformações e apropriações, objeto de intervenções é, ao mesmo tempo, "a maquinaria e o herói da modernidade".

Nas intervenções urbanas de Salvador, podemos identificar essas operações. Em primeiro lugar, havia o discurso de que as reformas eram necessárias para sanear, higienizar e modernizar a cidade. Os avanços progressistas e civilizadores esbarravam nos antigos edifícios (considerados escombros e ruínas coloniais que comprometiam a circulação de veículos), alargar ruas e abrir novas avenidas para facilitar o tráfico, principalmente para construir as linhas dos bondes.

Apesar das intervenções terem começado no final do oitocentos, a população não aceitava facilmente as demolições, principalmente das igrejas. Ou seja, a execução do projeto modernizador dependia da força das autoridades para vencer as resistências teimosas das tradições. Os cortes na Igreja do Corpo Santo comprometiam as práticas religiosas de duas irmandades: Senhor Bom Jesus das Necessidades e Senhor da Redenção (formada pelos africanos do Daomé, em 1752) e Glorioso Patriarca S. José (1891), além de devoções praticadas por grupos católicos não organizados, como os devotos de Santa Bárbara que eram trabalhadores do Mercado de Santa Bárbara, onde existia 
um nicho da mártir, mas mandavam celebrar missas e guardavam suas alfaias (objetos de culto em ouro e prata) nessa igreja. Assim, quando as intervenções aconteciam, os irmãos e devotos eram obrigados a transferir, mesmo que provisoriamente, suas imagens e alfaias para a Igreja de Nossa Senhora da Conceição da Praia, localizada no mesmo distrito.

A maior reação à modernização arquitetônica ocorreu quando os monges beneditinos receberam o comunicado de que o Mosteiro de São Bento receberia cortes. O abade Majolo de Caigny ${ }^{16}$, juntamente com os fiéis que frequentavam a igreja, organizou manifestações contrárias às demolições. Ele escreveu manifestos e os publicou nos principais jornais da cidade, escreveu e distribuiu panfletos e organizou um número especial da revista feminina A Paladina do Lar composto de textos dedicados a discussão do "projeto demolidor", planta antiga da construção das dependências do mosteiro e nova planta para demonstrar o que seria modificado. Os protestos, pelo menos em parte, foram vitoriosos, pois o mosteiro perdeu apenas a varanda lateral.

Os antigos prédios, inclusive as igrejas coloniais, eram vistas pela gestão funcionalista como detritos, empecilhos ao progresso. Porém, os gestores públicos contavam com o espírito patriótico e inovador do arcebispo da Bahia, dom Jerônimo da Silva, que, como foi abordado anteriormente, facilitava as reformas ao solicitar à Sé romana as licenças para as demolições de igrejas e convencer seus fiéis, nem sempre adeptos das mudanças, de que deslocamentos de devoções e bens religiosos eram necessários ao bom funcionamento da cidade moderna e civilizada que se desejava.

Apesar dos protestos, duas importantes igrejas da capital - São Pedro Velho (construída em 1785) e Sé (construída em 1552) - foram totalmente destruídas, em 1913 e 1933 respectivamente. Em 17 de abril de 2013, o jornal Diário de Notícias anunciava que no dia 15 do corrente aconteceu, no Palácio Rio Branco (sede do governo), a assinatura da escritura, lavrada em cartório, da desapropriação da Igreja de São Pedro Velho. ${ }^{17}$ A partir de então, o mesmo jornal passou a anunciar a realização da última missa "em virtude de desaparecer este templo, do lugar em que, há séculos, se acha, para dar lugar às obras da grande avenida de $\mathrm{S}$. Bento à Barra" 18 . Informava ainda que a missa seria celebrada pelo arcebispo e que depois se faria a transladação do Santíssimo Sacramento para a igreja do Convento da Lapa e que deveriam comparecer todas as irmandades para o culto do corpo de Cristo.

A última missa foi celebrada em 25 de abril de 1913 e foi comentada nos jornais como um grande acontecimento. De fato, as descrições demonstram que houve pompa. Dom Jerônimo da Silva estava acompanhado do vigário da freguesia de S. Pedro, Francisco de Assis Pires, dois monsenhores e outros padres seculares e regulares. A procissão em direção ao Convento da Lapa (sede provisória da freguesia) foi iniciada com o pálio que cobria o Santíssimo Sacramento, seguido dos religiosos. Como demonstração da 
importância da demolição para a efetivação do projeto, algumas autoridades civis acompanharam toda a solenidade. Seguiam o préstito, o representante do governador, o secretário geral, o chefe de polícia e seu chefe de ordens, o diretor das rendas do Estado e "outros cavalheiros da representação"19. Algumas associações leigas acataram a convocação para a última missa e a procissão de trasladação do Santíssimo Sacramento. Estavam presentes as irmandades sediadas no antigo templo - Santíssimo Sacramento, São Pedro, Santo Antônio de Cartagerona e Bom Jesus da Paciência - os irmãos de São Pedro das igrejas de Sant'Ana e do Pilar.

A Igreja da Sé foi um dos mais importantes templos do Brasil. A primeira Sé da colônia acolheu o primeiro bispo, Dom Pero Fernandes Sardinha. Porém, o templo teve ainda outras funções, como fortaleza militar durante a invasão holandesa. Os leigos, reunidos em várias irmandades nos seus altares laterais, custeavam as despesas, como os reparos do interior, adro e praça, e mantinham o fervor do catolicismo, com suas novenas, procissões e festas. Entretanto, sua importância religiosa e arquitetônica não foi suficiente para a sua preservação diante dos anseios modernizadores. Em seu lugar deveria passar uma linha de bondes. As dificuldades, como as negativas de autorização da demolição por parte da Santa Sé, atrasaram o projeto de demolição, que só se efetivou em 1933, quando a Bahia era governada Juracy Magalhães (1931-1937) e o arcebispado por dom Augusto Álvaro da Silva.

As demolições da Igreja de São Pedro Velho e da Igreja da Sé forçaram a transferência das associações leigas católicas para outros templos. Na tabela abaixo podemos observar os principais deslocamentos e a situação de cada grupo religioso a partir de 1913.

Tabela 1 - Associações leigas católicas em Salvador no século XX.

\begin{tabular}{|c|c|c|}
\hline Associação & $\begin{array}{l}\text { Espaço original nos séculos } \\
\text { XVIII e XIX }\end{array}$ & $\begin{array}{l}\text { Novo espaço } \\
\text { e situação no } \\
\text { século XX }\end{array}$ \\
\hline $\begin{array}{l}\text { Irmandade do Bom Jesus da } \\
\text { Paciência }\end{array}$ & Igreja de São Pedro Velho & $\begin{array}{l}\text { Igreja de São } \\
\text { Pedro - Praça } \\
\text { da Piedade }\end{array}$ \\
\hline $\begin{array}{l}\text { Irmandade de Santo Antônio de } \\
\text { Cartegerona }\end{array}$ & Igreja de São Pedro Velho & $\begin{array}{l}\text { Igreja de São } \\
\text { Pedro - Praça } \\
\text { da Piedade }\end{array}$ \\
\hline Irmandade de São Pedro & Igreja de São Pedro Velho & $\begin{array}{l}\text { Igreja de São } \\
\text { Pedro - Praça } \\
\text { da Piedade }\end{array}$ \\
\hline $\begin{array}{l}\text { Irmandade do S.S. Sacramento de } \\
\text { São Pedro }\end{array}$ & Igreja de São Pedro Velho & $\begin{array}{l}\text { Igreja de São } \\
\text { Pedro - Praça } \\
\text { da Piedade }\end{array}$ \\
\hline
\end{tabular}




\begin{tabular}{|c|c|c|}
\hline $\begin{array}{l}\text { Irmandade do S.S. Sacramento } \\
\text { da Sé }\end{array}$ & Igreja da Sé & $\begin{array}{l}\text { Antiga igreja } \\
\text { dos jesuítas - } \\
\text { nova catedral }\end{array}$ \\
\hline Irmandade de N. Sra. da Fé & Igreja da Sé & $\begin{array}{l}\text { Fusão com a } \\
\text { Srmandade da } \\
\text { Santíssima } \\
\text { Trindade }\end{array}$ \\
\hline $\begin{array}{l}\text { Irmandade de N. Sra. da } \\
\text { Conceição Protetora dos Artistas }\end{array}$ & $\begin{array}{l}\text { Igreja de S. Francisco de Assis } \\
\text { Igreja da Sé (1893) }\end{array}$ & $\begin{array}{l}\text { Casa particular } \\
\text { sob a direção } \\
\text { do Sr. Alfredo } \\
\text { Villela }\end{array}$ \\
\hline Irmandade de Santa Cecília & Igreja da Sé & Sem informação \\
\hline $\begin{array}{l}\text { Irmandade de N. Sra. Rainha dos } \\
\text { Anjos }\end{array}$ & Igreja da Sé & $\begin{array}{l}\text { Igreja de N. } \\
\text { Sra. do Rosário } \\
\text { (Baixa dos } \\
\text { Sapateiros). } \\
\text { Fusão com a } \\
\text { Ordem Terceira } \\
\text { do Rosário }\end{array}$ \\
\hline $\begin{array}{l}\text { Irmandade de } \quad \text { S. } \\
\text { Alcântara }\end{array}$ & Igreja da Sé & $\begin{array}{l}\text { Antiga igreja } \\
\text { dos jesuítas - } \\
\text { nova catedral }\end{array}$ \\
\hline Irmandade de S. Vicente Ferré & Igreja da Sé & Extinta \\
\hline Irmandade de S. João Batista & Igreja da Sé & Extinta \\
\hline $\begin{array}{l}\text { Irmandade de N. Sra. de } \\
\text { Guadalupe }\end{array}$ & Igreja da Sé & Extinta \\
\hline \multicolumn{3}{|c|}{$\begin{array}{l}\text { Fonte: Livros de Correspondências dos arcebispos dom Jerônimo Tomé da Silva e dom } \\
\text { Augusto Álvaro da Silva no período de } 1893 \text { a } 1938 \text {. Arquivo da Cúria Metropolitana de } \\
\text { Salvador - Laboratório Eugênio Veiga - LEV e jornal Diário de Notícias, } 1913 \text { - Biblioteca } \\
\text { Pública do Estado da Bahia - Seção de Periódicos. }\end{array}$} \\
\hline
\end{tabular}

Não sabemos exatamente quantas associações leigas eram sediadas nas igrejas demolidas no século XX. Por meio da documentação da Cúria Metropolitana de Salvador identificamos quatro irmandades na Igreja de São Pedro Velho e nove na Igreja da Sé. Para desapropriar a primeira igreja, dom Jerônimo da Silva exigiu que outro templo fosse construído. A nova Igreja de São Pedro foi construída na esquina da Av. Sete de Setembro com a Praça da Piedade, distante $260 \mathrm{~m}$ da antiga, onde restou como referência um monumento, o Relógio de São Pedro na Praça Barão do Rio Branco. A distância era pequena, mas a inauguração na nova igreja aconteceu em 1917. Durante esses quatro anos de espera não sabemos exatamente onde foram alojadas as irmandades. A documentação silencia, mas é provável que tenham sido acolhidas na Igreja do Convento da Lapa junto com o Santíssimo Sacramento.

Temos mais informações sobre as irmandades da antiga Sé por intermédio de um relatório ${ }^{20}$ apresentado pelo cônego Appio da Silva ao arcebispo dom Augusto Álvaro da Silva, em 1938. O documento apresenta a situação de oito irmandades. Elas foram distribuídas em diferentes igrejas. 
Das oito, apenas duas irmandades - Santíssima Trindade da Sé e São Pedro de Alcântara -se fixaram na igreja dos jesuítas convertida em catedral. Duas realizaram fusões. A Irmandade de Nossa Senhora da Fé se juntou aos irmãos da Santíssima Trindade e a Irmandade de Nossa Senhora Rainha dos Anjos se fundiu com a Ordem Terceira do Rosário passando a ocupar a Igreja de N. Sra. do Rosário na Baixa dos Sapateiros. A Irmandade de Nossa Senhora da Conceição Protetora dos Artistas passou a se reunir numa casa particular, provavelmente de um irmão. E três foram extintas. Infelizmente, o relatório não traz informações sobre a Irmandade de Santa Cecília, mas sabemos que ela estava ativa em 1931 por meio da resposta ${ }^{21}$ a um ofício encaminhado por dom Augusto Álvaro da Silva a todas as associações leigas, no qual solicitava informações sobre o funcionamento das mesmas.

Entretanto, só as demolições não seriam suficientes para desarticular as atividades das associações leigas. É preciso levar em consideração que o fim da escravidão (1888), a mudança de regime político, da monarquia para a república (1889) que contribuiu para a secularização dos cemitérios e do casamento civil, e a separação entre a Igreja e o Estado (1890) foram fatores que também provocaram mudanças nas práticas religiosas dos leigos católicos. Os vínculos de identidade étnica foram perdendo o significado inicial para a organização religiosa de africanos e seus descendentes. Além disso, desde o final do oitocentos, o catolicismo não era mais a única forma de crença existente na cidade do Salvador. O candomblé, apesar das perseguições, se consolidava como religião dos negros escravos e libertos; líderes religiosos de outras denominações cristãs, como presbiterianos, batistas organizavam igrejas e faziam o proselitismo; e os espíritas kardecistas desenvolviam suas atividades e propagavam suas crenças, ideias e literatura por meio da imprensa na capital e no interior. Ou seja, foram criadas outras formas de associações de ajuda mútua.

A Igreja Católica, para evitar a perda de fiéis e purificar as práticas religiosas dos leigos da inclusão de elementos de outras crenças, principalmente as afro-brasileiras, passou a supervisionar com mais rigor as associações católicas. O cumprimento da legislação eclesiástica ganhou força com a publicação do Código de Direito Canônico, em 1918. Baseados nas novas regras para a vivência religiosa dos leigos, como a supervisão e direção dos padres nas associações leigas católicas, os arcebispos dom Jerônimo Tomé da Silva (1893-1924) e dom Augusto Álvaro da Silva (1925-1968) foram muito mais rígidos nas cobranças dos relatórios, prestações de contas anuais, descrições dos bens e reformulação dos compromissos das irmandades, confrarias e ordens terceiras. Portanto, as intervenções urbanas juntamente com as mudanças políticas, sociais e religiosas fizeram com que muitas associações fossem extintas, realizassem fusões ou usassem diferentes táticas para burlar as normas e manter suas práticas religiosas. 


\section{Novos espaços e perspectivas de continuidade}

Para compreender o significado dos deslocamentos feitos pelas associações leigas na Salvador republicana não basta analisar os projetos de modernização e as intervenções urbanas que modificaram o mapa da cidade, principalmente das igrejas e suas devoções. É preciso entender o que as intervenções acarretaram na vivência religiosa. Quando uma igreja era derrubada, em parte ou na totalidade, algumas associações tinham que transladar suas imagens, alfaias e objetos de culto para outro templo.

Alguns estudiosos do espaço, como Yi-Fu Tuan, fazem uma diferenciação entre espaço e lugar. Ambos são pautados na experiência, mas o espaço é a amplidão, ao mesmo tempo da liberdade e da ameaça, enquanto o lugar é o que conhecemos melhor, dotamos de valor e nos dá a sensação de familiaridade, segurança e estabilidade. Dessa forma, "o espaço transforma-se em lugar à medida que adquire definição e significado"22.

Essa também é a perspectiva de Michel de Certeau. Ele define o espaço como um "lugar praticado" 23 . Ou seja, uma nova rua ou avenida definida pelo urbanismo só se torna espaço por meio das práticas e experiências cotidianas dos pedestres. Assim, a oposição entre lugar e espaço remetem a duas determinações: por objetos, como as pedras do calçamento que fundam uma rua, ou por operações, que condiciona um espaço a partir das ações dos sujeitos históricos. Até aqui tratamos espaço e lugar como categorias geográficas, mas o que acontece quando esses sujeitos são praticantes de uma religião? Para o homem religioso, o espaço não é homogêneo, possui roturas, quebras. Há espaço forte, significativo, sagrado, e espaço sem estrutura, caótico, não sagrado.

De acordo com Mircea Eliade ${ }^{24}$, é a experiência religiosa da não homogeneidade do espaço que permite a constituição do mundo. É preciso encontrar um ponto fixo, um eixo central de orientação. Por meio dele é possível fundar o mundo. A experiência religiosa estabelece o centro do mundo, que pode ser representado por alguns elementos, como uma madeira fincada no chão, árvore, montanha, templo, escada, cruz, etc., cuja função é marcar o centro sagrado, a partir de onde se pode construir as habitações, e, uma vez que esse elemento se encontra no meio, fazer a ligação entre "três zonas cósmicas" a terra, o céu e as regiões inferiores.

Todo templo é um eixo de ligação entre os mundos, porém significa ainda "a reprodução terrestre de um modelo transcendente" 26 . Em qualquer religião, é o lugar sagrado por excelência, é o santuário purificado, a casa dos deuses, portanto, a partir dele se estabelece um espaço sagrado. Para os cristãos, a igreja representa a cidade de Jerusalém, o paraíso e o mundo celeste. A partir do momento em que se atravessa a porta, o limiar entre os espaços, o fiel abandona o profano e adentra o recinto sagrado, encontra o seu lugar, o 
seu centro, o eixo que, simbolicamente ou ritualmente, permite a comunicação com Deus e o transporta para o paraíso.

É preciso ressaltar ainda que o espaço sagrado não é apenas um local físico, e sim, demarcados pelo "poder da mente de extrapolar muito além do percebido" 27 , de materializar imagens, sentimentos e pensamento. De acordo com Zeny Rosendahl, "[...] cada comunidade religiosa recorda o espaço à sua maneira, de forma a constituir um ponto fixo em que ela se confina, onde ela reencontra suas lembranças" ${ }^{28}$. Não por acaso, quando o fiel passa a frequentar uma igreja, procura o seu lugar. Ou seja, busca dentro do espaço sagrado um lugar de identificação, que pode ser a proximidade de uma imagem do santo da sua proteção. Por isso, quando a frequência ao culto cria laços de sociabilidade e a necessidade de se associar a outros indivíduos da mesma devoção, formase a irmandade.

Ter um espaço próprio era, e ainda é, uma necessidade para as associações desde o momento em que são criadas. Após escolher um santo de devoção, o grupo estabelecia suas regras, compondo um regimento interno, o compromisso ou os estatutos, e buscava sua aprovação pela autoridade eclesiástica. Normalmente, o culto começava em um altar lateral de uma determinada igreja, onde já se reuniam. Porém, o objetivo era arrecadar fundos para a construção do templo, que já é espaço sagrado, mas com a convivência dos irmãos e a realização dos seus rituais e suas festas, torna-se o lugar das associações leigas.

Entretanto, esse espaço/lugar sagrado é de uso coletivo e também palco de disputas e conflitos. Então, cada irmandade, confraria ou ordem terceira procura estabelecer ainda mais seu lugar. Daí a importância dos altares laterais, cada um ocupado por um grupo de irmãos e sua devoção. A imagem do orago, as alfaias, orações, novenas, procissões e festas a ele dedicado dão significado ao lugar. E assim, os lugares sagrados se multiplicam dentro do espaço sagrado que é a igreja.

$\mathrm{Na}$ igreja e no altar estão impressas as marcas materiais e imateriais da devoção, como seus sentimentos, crenças, mitos e visões de mundo. Por isso, os deslocamentos de espaços sagrados são tão traumáticos para os irmãos reunidos em associações. Poderíamos pensar que é apenas uma mudança de uma igreja para outra, de um espaço sagrado para outro. E muitas vezes as autoridades eclesiásticas tratam a transferência dessa forma, como se bastasse celebrar uma missa e fazer a trasladação das imagens. Porém, para os devotos, mudar de igreja significa a perda do seu ponto fixo, do seu eixo de orientação, do seu centro do mundo. Simbolicamente é o retorno ao caos. Mais grave ainda é quando o templo é destruído. A promessa de um novo espaço pode se efetivar, mas não resolve a questão.

A transferência de igreja implica, necessariamente, numa nova sacralização e na reestruturação devocional dos fiéis e da sua associação. É 
preciso restabelecer o ponto fixo. E a distribuição dos altares e capelas e a disposição das imagens sacras requisitam novos rituais. Novamente, cada grupo de irmãos procura, dentro do espaço sacralizado, o seu lugar. Além disso, estão em jogo as relações de poder entre os clérigos e os vários grupos leigos para a utilização desse espaço. Portanto, mesmo a igreja, para onde se fez a mudança, sendo também um lugar sagrado, tornam-se necessários avisos, pedidos de licença e negociações para a instalação de um novo grupo.

Não era incomum uma associação leiga realizar deslocamentos, principalmente quando não tinha uma igreja própria. Geralmente, existiam dois tipos de mudança de sede: uma voluntária, quando os próprios irmãos, por algum motivo nem sempre explícito na documentação, decidiam mudar de igreja. E outra involuntária, decidida pelas autoridades eclesiásticas. Porém, qualquer que fosse o tipo de mudança, a associação dependia da acolhida por parte de outras já estabelecidas nos altares do templo requerido Essa situação sempre gerava algum desconforto, quando não conflitos.

Em Salvador temos um exemplo de uma irmandade que realizou, em três diferentes ocasiões, os dois tipos de deslocamento. Trata-se da Irmandade de Nossa Senhora da Conceição Protetora dos Artistas que foi criada na Igreja de São Francisco de Assis. Em 1893, sem deixar claro o motivo, solicitou ao arcebispado a transferência para a Igreja da Sé e, após a demolição desta, em 1933, ficou sem templo, realizando reuniões em casa particular, como informou o cônego Appio Silva ${ }^{29}$, em 1938.

O primeiro deslocamento foi voluntário. Um ofício ${ }^{30}$ enviado pela Irmandade de Nossa Senhora da Conceição Protetora dos Artistas ao bispo capitular, em 02 de abril de 1893, cujo assunto é a solicitação de licença para a transladação da imagem da padroeira para a Igreja da Sé, nos dá a dimensão das negociações e dificuldades enfrentadas pelas associações leigas para a realização das mudanças de espaço. O documento revela que os irmãos, em primeiro lugar, informaram ao arcebispado o desejo de se transferirem para a Igreja da Palma. Foram orientados a informar o pedido de mudança de sede às irmandades sediadas naquela igreja: Nossa Senhora da Palma e Senhor Bom Jesus da Cruz. Tudo indica que não houve acolhida, pois o secretário João Justiniano de Figueiredo, que assina o documento, apenas informa que assim o fizeram, porém, tinham enviado ofício também ao juiz da Irmandade do Santíssimo Sacramento da Sé (certamente receberam o aceite) e, portanto, requeriam a transferência para a Igreja da Sé.

A segunda mudança foi involuntária em função da demolição da Sé Primacial. Esse deslocamento provocou um trauma maior. Não encontramos documentos que deem conta das negociações para a transferência da irmandade no século XX, mas, provavelmente, os irmãos não obtiveram nenhum bom resultado, uma vez que o último documento que informa sobre a associação, afirma que as reuniões aconteciam em uma casa particular do Sr. Alfredo Villela 
(provavelmente um associado), situação que revela precariedade e perda da oficialidade do culto.

A mudança de igreja também comprometia a gestão das receitas e dos bens da associação. Appio Silva, ao relatar a situação da Irmandade de Nossa Senhora da Conceição Protetora dos Artistas, afirma que solicitou informações e documentos da associação, mas que o Sr. Alfredo Villela entregou apenas alguns "talões de recibos da vendagem dos poucos carneiros, nas Quintas" 31 e que de alfaias e bens, a irmandade possuía apenas a imagem da padroeira e uma caderneta de poupança na Caixa Econômica Federal. Uma das principais funções de uma associação leiga era promover os ritos fúnebres e custear o enterro cristão de seus associados. Quando a associação não possuía cemitério próprio, comprava carneiros em um cemitério público. Portanto, essa informação da venda dos carneiros na Quinta dos Lázaros demonstra que já não era possível cumprir essa regra do compromisso.

Entretanto, houve resistências às transferências de espaço sagrado. Os irmãos, reunidos nas nove irmandades da Igreja da Sé, utilizaram táticas, nem sempre visíveis, para demonstrar descontentamento em relação às estratégias ${ }^{32}$ do arcebispado para enfraquecer suas devoções. Uma dessas táticas era não fornecer informações sobre suas atividades, por meio da insistente solicitação de relatórios e inventários dos seus bens, vindas do próprio arcebispo ou do cabido diocesano.

Em 1931, dois anos antes da demolição da Sé, os músicos reunidos na Irmandade de Santa Cecília responderam, de forma resistente e com queixa de falta de apoio do arcebispado, a mais um ofício de cobrança do cumprimento do Código de Direito Canônico. Quanto ao primeiro questionamento, se a associação tinha os estatutos organizados de acordo com a norma eclesiástica em vigor, o secretário respondeu que seguiam o compromisso legalmente aprovado pelo arcebispado em 1890. A segunda questão era sobre a prestação anual de contas. O secretário admitiu que a irmandade “[...] realmente não tem prestado conta de sua gestão ao Ordinário Diocesano, não por desobediência aos preceitos da lei invocada; mas sim, em virtude desconhecê-la e, nesta condição, os seus fundamentos" 33 . A mesa administrativa relevou dificuldades financeiras que quase causaram o seu desaparecimento, que não aconteceu graças à "perseverança e sincero amor e devoção" 34 à padroeira por parte dos associados.

$\mathrm{Na}$ verdade, a justificativa de não conhecer a nova legislação não eximia a irmandade da responsabilidade de prestação de contas prevista nas Constituições Primeiras do Arcebispado da Bahia, legislação eclesiástica em vigor do século XVIII a 1918. Então, não se trata de desconhecimento das normas, e sim, tática de resistência ao seu cumprimento.

Ainda sobre a exigência da prestação de contas e relatório dos bens das associações leigas, o cônego Appio Silva fez comentários reveladores no seu 
relatório. Primeiro explica que só obteve informações sobre oito das diversas irmandades e confrarias sediadas na antiga Sé por falta de acesso a livros e documentos. Tudo leva a crer que os músicos continuaram desobedecendo às ordens episcopais, pois a Irmandade de Santa Cecília nem aparece na relação do cônego da catedral. O silêncio parece ter sido a tática mais utilizada pelos irmãos para resistir à transferência forçada.

Ao relatar a situação da maior irmandade, a do Santíssimo Sacramento da Sé, Appio Silva que dom Augusto Álvaro da Silva não aprovou o compromisso reformulado (chamado de Estatutos após a publicação do Código de Direito Canônico, em 1918), "fato de que se originou a rebeldia da Mesa contra a Mitra" ${ }^{35}$ e a consequente destituição da mesa administrativa pelo arcebispo. Afirma, ainda, que ele não teve acesso aos documentos da mesma irmandade, pois estes estavam em mãos do "antigo secretário Nestor Behrens que se negou terminantemente a prestar quaisquer informação a respeito" ${ }^{36}$. E aproveitou a oportunidade para pedir permissão ao arcebispo "para lembrar a conveniência de ser o Cura da Catedral o presidente da Irmandade do S.S. Sacramento da Sé, cargo que sempre exerceu, como era do Compromisso, o antigo Cura da Sé" ${ }^{37}$. Um clérigo ser presidente de uma associação leiga tirava dela qualquer possibilidade de independência em relação ao clero e de gestão dos seus bens.

Dessa forma, a gestão dos bens das associações leigas da Igreja da Sé não estava mais a cargo das mesas administrativas, mas sim, a uma comissão formada pelos cônegos Appio Silva e Odilon Moreira e pelo senhor, identificado apenas como tesoureiro, Dr. Arthur Negreiros Falcão, membros escolhidos pelo arcebispo. Ou seja, as irmandades desalojadas perderam totalmente a autonomia. Todas possuíam alfaias, apólices, cadernetas de poupança e carneiros no Cemitério Quinta dos Lázaros.

A Irmandade do S.S. da Sé, apesar de admitida na catedral, não teve seu compromisso aprovado e sua mesa administrativa foi destituída pelo arcebispo. Apesar dessa situação, Appio Silva relatou que a irmandade, desde 1936, pagava os honorários do capelão da catedral, Odilon Moreira, e um auxílio ao zelador Alfredo Villela.

Toda irmandade, confraria ou ordem terceira tem como principais objetivos realizar o culto ao santo escolhido como protetor e praticar a ajuda mútua entre os membros. Ou seja, socorrer os irmãos necessitados de ajuda material e espiritual durante a vida e, principalmente, realizar os ritos fúnebres e o enterro cristão necessários à salvação. Em 1931, a Irmandade de Santa Cecília, por meio de ofício ${ }^{38}$, enviou ao arcebispado a relação dos seus bens. Entre eles, estavam um "adereço da santa em ouro, prata e pedras preciosas", uma caderneta de poupança e "42 carneiros para adultos e 24 de anjos" no Cemitério Quinta dos Lázaros. Portanto, a mesa administrativa ainda garantia o enterro dos associados e seus filhos (adultos ou crianças).

Sabemos, por intermédio da documentação referente às associações 
leigas no século $\mathrm{XX}$, que algumas ainda mantinham os ritos fúnebres e enterros, porém, ao mesmo tempo, demonstra que as irmandades transferidas da Sé tinham mais dificuldades para enterrar seus associados nos cemitérios públicos, pois perderam também a gestão desses espaços e das práticas fúnebres. A comissão da catedral seria responsável por cuidar dos carneiros. Em caso de fusão com outra associação, a receptora ficava de posse desse bem. Esse foi o caso da Irmandade de Nossa Senhora da Fé, que ao ser incorporada à Irmandade da Santíssima Trindade, deveria fazer a entrega dos seus carneiros.

O relatório de Appio Silva revela outra fragilidade das irmandades transferidas para a catedral: a falta de realização das festas anuais. Ora, essa era a principal obrigação dos irmãos para com seus patronos. Uma associação leiga só deixava de festejar quando não encontrava nenhuma possibilidade financeira e de organização para homenagear seu santo de devoção com pompa. O documento ${ }^{39}$ revela que a Irmandade do S. S. Sacramento da Sé, no período de cinco anos, havia realizado apenas duas festas após a transferência. Para garantir o bom funcionamento dos rituais, liturgia e festa era imprescindível a permanência em um lugar de culto, o altar principal de um templo próprio ou, na impossibilidade dessa aquisição, um altar lateral de outra igreja.

Ter sede própria dava a associação leiga a estabilidade, as receitas necessárias e também certo poder e autonomia em relação ao arcebispado. Caso contrário, era preciso buscar outras alternativas, se adaptar às normas e às mudanças impostas pela Igreja Católica e as autoridades civis modernizadoras ou resistir, de forma astuciosa ganhar tempo e transformar a ocasião numa perspectiva de continuidade.

No alvorecer do século XX é certo que as associações leigas, principalmente as de negros e pardos, perderam parte do seu sentido, uma vez que já não eram tão importantes para agrupar pessoas de uma mesma identidade étnica. Porém, havia permanência de outras funções, como a difusão do culto aos santos e a promoção da ajuda mútua. Os irmãos de fé católica procuravam manter suas devoções e festas, obrigações com os seus patronos. E, na precariedade do Estado para oferecer saúde, assistência aos enfermos e enterramento cristão, ainda eram fortes e eficazes os laços de solidariedade entre os associados. Portanto, ainda havia sentido em se associar, e, para o historiador das religiões e religiosidades, é preciso importante definir as funções dos grupos religiosos e compreender o lugar ocupado pelas irmandades, confrarias e ordens terceiras na sociedade brasileira republicana.

Especialmente nas grandes cidades do século XX, houve mudanças significativas nos aspectos político, socioeconômico e religioso. Enquanto a elite branca e letrada defendia a modernização das áreas urbanas e a civilização dos costumes, os menos favorecidos também desejavam a chegada dos avanços científicos para usufruir de melhores meios de transporte, da iluminação pública, das obras de saneamento e do embelezamento dos novos prédios, 
ruas e avenidas. Porém, no que diz respeito às mudanças na vivência religiosa, todos, independentemente de classes sociais, seriam atingidos. As demolições de espaços sagrados, como as igrejas de São Pedro Velho e Sé, provocaram os deslocamentos de irmandades de brancos, pardos e negros, sejam membros da aristocracia ou das classes menos favorecidas.

As autoridades eclesiásticas, com a intenção de reformar a religiosidade leiga, de forma estratégica, aproveitavam as intervenções urbanas para minar a independência das mesas administrativas. As irmandades forçadas ao deslocamento, teriam que se submeter às normas e interferências do pároco da igreja que as recebia. $\mathrm{O}$ arcebispo criava comissões para inventariar e gerir os bens das associações e também supervisionar suas práticas religiosas, tirando delas a autonomia administrativa e devocional.

Nesse contexto de reformas e desarticulação das práticas devocionais, os fiéis católicos utilizaram diferentes táticas para manter suas atividades, desde a fusão entre irmandades ou de irmandade com ordem terceira, à recorrência aos períodos de silêncio e de não dar resposta aos ofícios do arcebispado até a resistência a entregar às autoridades eclesiásticas os documentos e alfaias. Essas táticas não foram completamente vitoriosas, mas garantiram a permanência de algumas associações pelo menos até a segunda metade do século XX. Certamente, ter uma igreja própria aumentava a perspectiva de continuidade das práticas leigas. As ordens terceiras geralmente tinham mais status social e maior estabilidade, pois estavam sediadas nas igrejas das ordens primeiras às quais estavam vinculadas ou construíram seus próprios templos. Já as irmandades e confrarias estavam mais fragilizadas, suscetíveis às mudanças de espaço e aos riscos de extinção.

\section{Notas de Fim}

1 Cf. Tavares, Mauro Dillmann. Irmandades, Igreja e Devoção no Sul do Império do Brasil. São Leopoldo: Oikos, 2008; COUTO, Edilece S.. Festas afro-católicas em Salvador, Bahia, Brasil. Revista del CESLA, v. 18, p. 117-142, 2015.

2 BOSCHI, Caio César. Os leigos e o poder: irmandades leigas e política colonizadora em Minas Gerais. São Paulo: Ática, 1986, p.12-21.

3 COMPROMISSO da Confraria do Senhor Bom Jesus da Cruz. Salvador: Typographia Liberty, 1914. Arquivo da Cúria Metropolitana de Salvador - Laboratório Eugênio Veiga - LEV, p. 6.

4 RUSSEL-WOOD, A. J. R. Fidalgos e filantropos: a Santa Casa da Misericórdia da Bahia, 1550-1755, Brasília: Ed. UnB, 1981; A. Garcez, Ordem Terceira de São Francisco de Assis da Bahia, Salvador: EDUFBA, 2007.

5 COMPROMISSO..., Op. Cit., p. 1.

6 SILVA, Macânio José da. Ofício da Irmandade de Santa Cecília ao vigário capitular Manoel dos Santos Pereira. Salvador, 17 jun 1891. Laboratório Eugênio Veiga - LEV, p. 1. 
7 COMPROMISSO..., Op. Cit., p. 7.

8 CERTEAU, Michel de. A invenção do cotidiano. 1. Artes de fazer. Petrópolis: Vozes, 1998, p. $47,100-102$.

9 BENJAMIN, Walter. Paris, capital do século XIX. In: KOTdHE, Flávio R. (Org.) Walter Benjamin - Sociologia. São Paulo: Ática, p. 30-43, 1985.

10 COSTA, Ângela M. da; SCHWARCZ, Lilia Moritz. 1890-1914: No tempo das certezas. São Paulo: Companhia das Letras, 2000 (Virando Séculos), p. 32-33.

11 Ibidem, p.30.

12 COUTO, Edilece S. "A Bahia não se desnacionaliza”: modernidade, civilidade e permanência dos costumes na Salvador republicana. In: MOURA, Milton (Org.). A larga barra da baía: essa província no contexto do mundo. Salvador: EDUFBA, 2011, p. 68-70.

13 Ibidem, p. 72-73.

14 Apud BARBOSA, Manoel de Aquino. Efemérides da freguesia de Nossa Senhora da Conceição da Praia. Salvador: Beneditina, 1970, p. 147.

15 CERTEAU, Michel de. Op. Cit., p. 173-174.

16 CAIGNY, Majolo de. A Paladina do Lar, nº 9, Salvador: Typographia Benedictina, 1912.

17 DIARIO de Notícias. Egreja matriz de são Pedro. Salvador, 17 abr. 1913, p.1. Biblioteca Pública do Estado da Bahia - Seção de Periódicos. A grafia das palavras foi atualizada.

18 Ibidem.

19 DIARIO de Notícias. Última missa. Salvador, 26 abr. 1913, p.1. Biblioteca Pública do Estado da Bahia - Seção de Periódicos.

20 SILVA, Appio. Relatório das irmandades, confrarias e devoções existentes na antiga Igreja da Sé. Salvador, nov. 1938. Arquivo da Cúria Metropolitana de Salvador - Laboratório Eugênio Veiga - LEV, p. 1-5.

21 SILVA, Macânio José da. Op. Cit, p.1.

22 TUAN, Yi-Fu. Espaço e lugar: a perspectiva da experiência. São Paulo: DIFEL, 1983, p. 151.

23 CERTEAU, Michel de. Op. Cit., p. 202.

24 ELIADE, Mircea. O sagrado e o profano: a essência das religiões. São Paulo: Martins Fontes, 1992, p. 25-61.

25 Ibidem, 42-46.

26 Ibidem, p. 55.

27 ROSENDAHL, Zeny. Espaço e religião: uma abordagem geográfica. Rio de Janeiro: EdUERJ/NEPEC, 1996, p. 33.

28 Ibidem, p. 35.

29 SILVA, Appio. Op. Cit, p. 3.

30 OFÍCIO da Irmandade de Nossa Senhora da Conceição Protetora dos Artistas ao bispo capitular. Salvador, 02 abr. 1983. Arquivo da Cúria Metropolitana de Salvador - Laboratório Eugênio Veiga - LEV. 
31 SILVA, Appio. Op. Cit, p. 3.

32 Michel de Certeau define estratégia como o "[...] cálculo das relações de forças que se torna possível a partir do momento em que um sujeito de querer e poder é isolável de um 'ambiente'. Ela postula um lugar capaz de ser circunscrito como um próprio e portanto capaz de servir de base a uma gestão de suas relações com uma exterioridade distinta. A nacionalidade política, econômica e científica foi construída segundo esse modelo estratégico". CERTEAU, Michel de. Op. Cit., p. 47.

33 SOUSA, M. Zeferino de. Ofício da Irmandade de Santa Cecília. Salvador, 09 set. 1931, p.2. Arquivo da Cúria Metropolitana de Salvador - Laboratório Eugênio Veiga - LEV.

34 Ibidem, p. 2.

35 SILVA, Appio. Op. Cit, p. 1.

36 Ibidem, p. 2.

37 Ibidem, p. 5.

38 MACHADO, Manoel Correia. Relação dos bens existentes na Irmandade de Santa Cecília. Salvador, 28 ago. 1931. Arquivo da Cúria Metropolitana de Salvador - Laboratório Eugênio Veiga - LEV.

39 SILVA, Appio. Op. Cit, p. 2.

Artigo recebido em março de 2017. Aceito em junho de 2017. 